NBER WORKING PAPER SERIES

\title{
PROFIT NEUTRALITY IN LICENSING: THE BOUNDARY BETWEEN ANTITRUST LAW AND PATENT LAW
}

\author{
Stephen M. Maurer \\ Suzanne Scotchmer \\ Working Paper 10546 \\ http://www.nber.org/papers/w10546
NATIONAL BUREAU OF ECONOMIC RESEARCH 1050 Massachusetts Avenue
Cambridge, MA 02138
June 2004

This paper profited from comments received from participants at the Antitrust, Patent and Copyright Conference held at Ecole des Mines de Paris (CERNA), jointly sponsored by Boalt School of Law, on January 15-16, 2004, from participants at Harvard Law School, March 23, 2004, and from participants at the annual meeting of the American Law and Economics Association, May 2004. We especially thank Louis Kaplow, Marty Adelman, Susan DeSanti, Carl Shapiro, and Mark Lemley for helpful comments. The views expressed herein are those of the author(s) and not necessarily those of the National Bureau of Economic Research.

(C)2004 by Stephen M. Maurer and Suzanne Scotchmer. All rights reserved. Short sections of text, not to exceed two paragraphs, may be quoted without explicit permission provided that full credit, including (C) notice, is given to the source. 
Profit Neutrality in Licensing: The Boundary between Antitrust Law and Patent Law Stephen M. Maurer and Suzanne Scotchmer

NBER Working Paper No. 10546

June 2004

JEL No. K21, L12, L24, L41

\title{
ABSTRACT
}

For over a century, courts and commentators have struggled to find principles that reconcile patent and antitrust law, especially as to patent licensing. We interpret case law and commentary to arrive at three unifying principles for acceptable terms of license. "Profit neutrality" holds that patent rewards should not depend on the rightholder's ability to work the patent himself. "Derived reward" holds that the patent holder's profits should be earned, if at all, from the social value created by the invention. "Minimalism" holds that licensing contracts should not contain more restrictions than are necessary to achieve neutrality. We argue that these principles largely rationalize important decisions of the twentieth century. They also justify the Supreme Court's controversial General Electric decision, which holds that patentholders can set prices charged by their licensees.

\author{
Stephen M. Maurer \\ 2607 Hearst Avenue \\ University of California \\ Berkeley, CA 94720-7320 \\ maurer@econ.berkeley.edu \\ Suzanne Scotchmer \\ 2607 Hearst Avenue \\ University of California \\ Berkeley, CA 94720-7320 \\ and NBER \\ scotch@socrates.berkeley.edu
}




\section{Introduction}

Patent law and antitrust concerns were born side by side. On the one hand, The Statute of Monopolies (1623) announced a general ban on monopolies "for the sole

Buying, Selling, Making, Working, or Using of any Thing within this Realm . . ." On the other, it created new monopolies as an incentive for inventions. The decision to treat the same legal concept - monopoly - as a crime in one case and a reward in the other presents unique problems for judges. “[B]ecause the patentee's authority is an island of permission in a sea of prohibition, there is no area at the edge of permission toward which the law is indifferent: what is not authorized is forbidden." (Baxter 1966). Expanded antitrust enforcement during the twentieth century has made this problem increasingly acute.

Over the past century, courts and commentators have explored many different proposals for defining the boundary between intellectual property and antitrust law. The simplest approach, "inherency," resolves the issue by allowing one body of law to dominate the other in any conflict (Adelman and Juenger 1975). Early in the twentieth century, patent law dominated so that restrictive licenses were generally upheld. During the 1960s, some commentators urged a different version of inherency that would have made antitrust dominant (Kaplow 1984). Although generally disfavored, inherency arguments are still being made (Gifford 2002; Patterson 2000).

The alternative to inherency is balancing. However, if antitrust and patent law have different objectives, it is not obvious how to strike a balance. For this reason, most commentators have advocated balancing according to a single, agreed-upon objective such as "wealth maximization" or "consumer welfare" (Bork 1965, 1978; Bowman 1973). But even with a single, common objective, there is no obvious calculation that courts should use to balance ex ante incentives against ex post deadweight loss. Almost all cases and commentators argue that courts should infer the correct balance from Congress's intent as codified in the patent laws.

There are many different ways to divine intent. Twentieth century judges and 
scholars have offered a bewildering variety of schemes for balancing. In general, there are two schools. The earliest, which dates from the 1920s, seeks to develop clear per se rules that can be applied more or less mechanically. Courts following this tradition have approved restrictions on licensees' prices (General Electric 1926), on licensees' customers (General Talking Pictures 1938; Schlicher 2002) and on licensees's geographic markets (Hovenkamp, Janis \& Lemley 2004). Over time, the Supreme Court seems to have lost confidence in the per se agenda. In fact, the Court came within one vote of overruling General Electric in 1948 and again in 1965. Lower courts have also adopted exceptions, ${ }^{1}$ to the point where many commentators argue that General Electric is a "vestige" that prudent practitioners should not rely on (Weinschel 2000). Nevertheless, it remains the law of the land.

The second school, dominant since the 1940s, argues for a more flexible "ruleof-reason" standard. ${ }^{2}$ Courts currently use rule of reason for a wide variety of license restrictions (Weinschel 2000 at 2:90). However, this program has yet to develop any widely-recognized principles or rules for deciding cases. At its worst, "rule of reason" can be little more than a label disguising "amorphous" and "freewheeling" standards. (Juenger \& Adelman 1975) Since the 1980s, however, scholars have thought hard about the inquiries that any principled rule of reason approach must resolve.

Despite occasional claims of an emerging paradigm (Gifford 2002), most commentators agree that current law is unsatisfactory (Kaplow 1984). In the words of one

\footnotetext{
${ }^{1}$ For example, General Electric may not apply to the unpatented product of a patented machine (Weinschel 2000; Hovenkamp, et. al., 2004), to patentholders with multiple licensees (Weinschel 2000; Hovenkamp, et. al., 2004), to patentholders who do not manufacture the patented item (Schlicher 2002; Hovenkamp, et. al., 2004; Royal Industries 1969), to licenses that are said to "predominantly benefit" licensees rather than the patentholder (Weinschel 2000; Ethyl 1940), to licenses where the patent does not "completely cover" the product (Schlicher 2002; Hovenkamp, et. al., 2004), to patentholders who acquire their rights by purchase rather than internal R\&D (Hovenkamp, et. al., 2004), or to intellectual property rights other than patents (Hovenkamp, et. al., 2004; Interstate Circuit 1939).

${ }^{2}$ Although we find it convenient to speak of per se and rule of reason approaches as opposites, the truth is considerably more complicated. The Supreme Court has warned that "there is often no bright line separating per se from Rule of Reason analysis." (California Dental Assn. 1984). Instead, judges who apply rule of reason must still be guided by our general knowledge of economic theory. (Areeda \& Hovenkamp, 2003). Conversely, judges must be prepared to change per se rules, however reluctantly, as knowledge and experience accumulate. (Id.)
} 
leading commentator, "[f]rom the decisions, it is clear that the courts lack a clear and general theory for resolving that inquiry. Thus, individual problems are resolved in a piecemeal fashion, and it is difficult to harmonize decisions in one area (such as price restrictions) with another (such as field of use restrictions)." (Chisum 2003) This doctrinal confusion has practical consequences. Blue ribbon panels have complained since the 1950s that legal uncertainty deters patentees from licensing their inventions. (See Hensley 1967.)

In this paper we take a fresh look at the per se agenda, focusing mainly on the problem posed by General Electric - patent licenses featuring price restrictions. We start by stating three principles suggested - or at least consistent with - the case law and commentary that have developed over the past half-century. We see these principles as a normative foundation for addressing the patent/antitrust conflict, whether to justify per se rules, or to guide a rule-of-reason analysis. Needless to say, the motivating problem of price fixing does not exhaust the list of situations where antitrust and patent laws collide, ${ }^{3}$ and our three principles may not be useful in every instance. However, we show that they also apply to some provocative cases that involve improvement patents.

Section 2 explains the three princples, and how they relate to case law and commentary. In section 3, we analyse the licensing of a product patent, as in General Electric. In section 4 we consider product enhancements or additives as in Ethyl Gasoline and Line Material. In section 5 we list three possible per se rules and analyse their strengths and weaknesses. In section 6 we compare rule of reason's strengths and weaknesses with a revived per se approach. Section 7 is a short conclusion.

\footnotetext{
${ }^{3}$ Prominent examples include tying, field of use and geographic restrictions, package licensing, post-expiration royalties, grant-back provisions, the first sale doctrine, restrictions on users' right to repair patented machines, settlement agreements, and agreements that extend rights beyond the scope of the antitrust laws.
} 


\section{The Three Principles}

By the 1920s, the Supreme Court had abandoned the inherency view that a patent holder could impose whatever license restrictions he desired. When the Court concluded that at least one license restriction (tying) violated the antitrust laws, they opened the door to questioning others. Which restrictions should be legal and which not? The General Electric opinion announced a new standard: In order to be lawful, license restrictions would have to be "reasonably adapted to secure pecuniary reward for the patentee's monopoly." (General Electric 1926) As Kaplow (1984) remarks, most courts and commentators seem to believe that this phrase entitles the patentee to a "specific level of aggregate reward." In our view, however, a better and more plausible interpretation is that courts should ask whether the patentee's methods are reasonable while remaining agnostic about whether the amount of the reward is reasonable. Commentators have also stressed that an ability to exploit patents through licensing is needed to reward small independent inventors and businesses, discourage inefficient integration, and put production in the hands of the most efficient manufacturer (Landes \& Posner 2003; Bowman 1973). ${ }^{4}$

We argue that most twentieth-century jurisprudence about licensing can be summarized in three principles: profit neutrality, derived-reward, and minimalism. Together, these principles strike us as a sensible guide for a revitalization of per se rule-making, but could alternatively be construed as a constraint on the inquiries that underlie a rule-of-reason analysis.

Profit neutrality is our label for the principle, implicit in General Electric, that a patent reward should be the same as if the patent holder had the ability to work the

\footnotetext{
${ }^{4}$ To the best of our knowledge, Professor Baxter (1966) is the only commentator who has stated profit neutrality in substantially the same form adopted here: "[I]t could be said, the economic value of the invention is best measured by the extent of restriction and profits that would attend direct patentee exploitation; and to prevent the patentee from capturing a part of these incremental profits by splitting them with licensees on whom he has conferred sheltered positions is to deprive the patentee of part of that value." After stating it, Baxter rejected this argument because he believed that companies that held strong patents would always prefer vertical integration to licensing. Hence, any licenses that did exist were likely to be shams. Baxter's view followed from his conclusion that licensors could not recover $100 \%$ of its licensees' profit. We disagree.
} 
patent efficiently himself. The patent holder's ability to work the patent may depend on such accidents of history as whether he owns manufacturing facilities, is liquid, or has access to financing. Licensing may be the only way to overcome such limitations. The profit-neutrality principle allows us to measure licenses against the benchmark of what the rightholder could hypothetically earn through complete vertical integratation if he controlled the efficient means of production.

Of course, to evaluate whether a given license term is required for profitneutrality, the court needs to assess the market consequences with and without the disputed term of license. This is a fallible process. The economic reasoning in General Electric was clearly inadequate. The Court paraphrased the rightholder's goals as, "Yes, you may make and sell articles under my patent, but not so as to destroy the profit that I wish to obtain by making them and selling them myself." As Bowman (1973) has remarked, "surely it is net receipts that should interest General Electric rather than the sheer accounting joy of attributing profits to its own manufacturing operations." Whether or not profit neutrality was in the Court's mind, the justices certainly lacked the economics modeling tools to implement it.

Derived reward is our label for the principle that the patent holder must earn her reward, if at all, from the social value of the invention. The Supreme Court has held that a license cannot be used to create a monopoly on any product other than the invention itself (Schlicher 2002) and that the patent monopoly should exclude "all that is not embraced in the invention" (Morton Salt 1942). In fact, any other stance would be unconstitutional. Neither Congress nor the courts can give a patentee "more than the rewards of his discovery" (Hensley 1967; see also Line Material 1948 (Douglas concurring)).

Since the 1960s, commentators have struggled to give a precise economic meaning to these judicial insights. Suggestions include that revenue should be tied to the utility the patented product provides to users (Baxter 1966), that rewards should "measure[] the patented product's competitive superiority over substitutes" (Bowman 1973), "never compensat[ing] the patentee beyond the value of his invention to soci- 
ety" (Adelman \& Juenger 1975), and that steps should be taken to "ensure that the return on intellectual property is related to its value" (Patterson 2000). Among other things, such interpretations condemn sham licenses. In a sham license, the intellectual property right is an excuse to create a cartel that would be profitable even if the invention had no value.

An important nuance is whether the court should be concerned with the size of the reward or the source of the reward. Under our derived-reward principle, the court should consider the source, not the size. If concerned with the size, the court might allow terms of license that cartelize a pre-existing market, on a theory that such cartelization is necessary to reimburse the innovator's costs. Such leniency could subvert the incentive purpose of the patent grant. If the patentee cannot be rewarded out of the value created, then the innovation was probably not socially desirable in the first place. We admit, of course, that even under our derived-reward principle, socially efficient innovations may be underrewarded. If that is too common an occurrence, then Congress should revise the design of the patent right.

In the 1940s, the Supreme Court became increasingly willing to find that firms overstepped the bounds of the patent right, especially in condemning tying, which seemed to allow patent holders to "leverage" the patent monopoly into new markets. Although the Court may have been using faulty economics, ${ }^{5}$ commentators did not seriously challenge the prohibition on tying until the late 1950s.

Minimalism is our label for the principle that licenses should be limited to as few restrictions as are necessary to achieve profit neutrality. Even commentators who approve of licensing admit that it "substantially increase[s]" the danger that the parties will organize illegal cartels (Bowman 1973). The General Electric rule, which offers immunity for price fixing, would be a particularly handy way for conspirators to implement collusion disguised as legitimate licensing (Ethyl 1940).

Courts and commentators have implicitly invoked minimalism to strike down license restrictions that seem superfluous. For example, Shapiro (1979) argued that

\footnotetext{
${ }^{5}$ For a recent discussion of the tying fallacy, see Posner and Landes (2003).
} 
the rightholder's power to restrict the sale of patented products should expire the first time a product is sold because "(t)he patentee can obtain the full reward of the patent in the first sale; a right to restrict the goods in more remote channels of trade is not a traditional part of the patent grant nor is it needed in order for the patentee to fully enjoy the monopoly of the patent." (emphasis supplied) Stronger versions of this argument have asserted that most license restrictions are invalid because "[a] rational patent owner can extract the full monopoly reward of the invention by setting appropriate royalties." Given this premise, additional restrictions in a license can only lead to implicit cartelization or bribe competitors not to invent around or challenge weak patents in court (Neal Report 1969).

Although we think that courts have been fairly clear on these three principles, we also think that they have sometimes been confused on the economic analysis that would allow the principles to be implemented. This discrepancy may account for much of the confusion and ambiguity in the case law and commentary.

\section{Licensing New Products}

We start by considering the original General Electric case, which concerned product patents. Profit neutrality implies that licensing should yield the same reward that a patentee would earn if all production was performed efficiently in-house. There are many reasons why the patent holder may not be situated to serve the whole market, such as that he cannot raise the money to build production or distribution facilities. Profit neutrality holds that the rightholder's reward should not depend on ownership of the plants that produce and distribute his patented product.

We first analyze a benchmark case, that the rightholder supplies the entire market directly. We then show that if all production is licensed to two licensees who can jointly supply the market efficiently, the patent holder can achieve the same profit using only fixed fees and per-unit royalties. Courts routinely approve fixed fees and royalties. We then turn to the intermediate case in which the patent holder supplies the market in competition with a licensee. This is the case that the Supreme 
Court faced in General Electric, and also in Line Material, in a slightly different circumstance. We show below that fixed fees and per-unit royalties cannot achieve efficient production or profit neutrality when the licensor and licensee compete, and when marginal cost is increasing. Perhaps surprisingly, it is the licensor's output that must additionally be constrained in that case, not the licensee's.

In what follows, we assume that the marginal cost of manufacturing is increasing, and that efficient production requires several plants instead of one. Accounting for plant setup costs, we assume without loss of generality that the efficient number of production facilities is two. Our focus is not on how many facilities will be used in production, but mainly on how production is distributed between them. Suppose that the inverse demand curve (the willingness to pay for the marginal unit at quantity $q$ ) is defined by $p(q)=1-q$, where $q$ is the total supply of all firms. ${ }^{6}$ When two plants supply the market with quantities $q_{1}, q_{2}$, the market price will therefore be $p\left(q_{1}+q_{2}\right)=1-\left(q_{1}+q_{2}\right)$. In this case the available profit as a function of total output is

$$
p(q) q-2 \int_{0}^{q / 2} \gamma(\hat{q}) d \hat{q}
$$

where $\gamma(\cdot)$ is the marginal cost curve in each facility. We ignore the fixed costs here, assuming that they justify the use of two and only two facilities.

\subsection{The Benchmark}

First suppose that the rightholder owns both facilities, decides how much to supply, earns all the revenue, and bears all the costs. The profit-maximizing total supply $q^{*}$, which maximizes (3.1), satisfies the condition that marginal revenue equals marginal

\footnotetext{
${ }^{6}$ The easiest interpretation is that each agent buys a fixed amount of the good in each period, which we shall understand as one unit. The potential buyers are indexed by their willingness to pay $\theta \in(0,1)$. If agent $\theta$ buys the good at price $p$, his utility is $\theta-p$. If $\theta$ is uniformly distributed on the interval $(0,1)$, the number of agents for whom $\theta-p>0$ is $1-p$. If $q$ units of the good are supplied, the market-clearing price is $1-q$, since that is the price that provides nonnegative utility to the $q$ buyers with $\theta>1-q$, but negative utility to the others.
} 
cost:

$$
1-2 q^{*}=\gamma\left(\frac{q^{*}}{2}\right)
$$

The profit-maximizing price satisfies

$$
p\left(q^{*}\right)=1-q^{*}=\frac{1}{2}\left(1+\gamma\left(\frac{q^{*}}{2}\right)\right)
$$

and the resulting profit is $p\left(q^{*}\right) q^{*}-2 \gamma\left(q^{*} / 2\right)-2 C$, where $C$ is the fixed cost of each production facility. This is the benchmark profit for profit neutrality.

\subsection{Licensing Out All Production}

Suppose instead that the patent holder relies on two licensees to supply the market. Profit is determined by the licensees' production decisions and shared with the licensor through royalties and fixed fees, $(\rho, F)$. We show that these instruments are sufficient to achieve profit neutrality.

We consider Cournot competition in which each licensee chooses its supply optimally assuming that the other firm's supply as given. Our objective is to characterize the equilibrium such that neither firm has an incentive to change its supply. The equilibrium supplies will depend on the royalty rate $\rho$. We will show that the following royalty rate supports the profit-maximizing price, with each firm supplying $q^{*} / 2$.

$$
\rho=\frac{1}{2} q^{*}
$$

Conditional on the royalty $\rho$, we will write profit of firm 1 as

$$
\left(p\left(q_{1}+q_{2}\right)-\rho\right) q_{1}-\int_{0}^{q_{1}} \gamma(\hat{q}) d \hat{q}
$$

Firm 1 takes the supply of the other firm, $q_{2}$, as fixed, and optimizes by choice of its own supply, $q_{1}$. The optimum satisfies

$$
q_{1}=\frac{1}{2}\left(1-q_{2}-\rho-\gamma\left(q_{1}\right)\right)
$$


Similarly, firm 2's profit as a function of $q_{2}$, taking $q_{1}$ as fixed, is

$$
\left(p\left(q_{1}+q_{2}\right)-\rho\right) q_{2}-\int_{0}^{q_{2}} \gamma(\hat{q}) d \hat{q}
$$

and the optimal $q_{2}$ satisfies

$$
q_{2}=\frac{1}{2}\left(1-q_{1}-\rho-\gamma\left(q_{2}\right)\right)
$$

Since the conditions (3.6) and (3.8) are satisfied at $\left(q_{1}, q_{2}\right)=\left(q^{*} / 2, q^{*} / 2\right)$ when $\rho$ is defined by (3.4), the profit-maximizing supplies $\left(q^{*} / 2, q^{*} / 2\right)$ are an equilibrium.

This assumes that the fixed fees are such that each licensee makes nonnegative

profit. If $\left(p^{*}-\rho\right)\left(q^{*} / 2\right)-\int_{0}^{q^{*} / 2} \gamma(\hat{q}) d \hat{q}>0$ the fixed fees can be positive, but otherwise must be negative. The fixed fees together with royalties can thus sustain the profitmaximizing price and transfer all the profit to the patent holder. (If negative fees are not allowed, an equilibrium with two licensees cannot be sustained.)

Thus, although patent holders have the right to impose quantity restrictions on their licensees (Schlicher 2002; Hovenkamp, et. al., 2004), profit neutrality does not generally require such restrictions in cases where the entire supply is contracted out.

\subsection{The Problem: Competition between Patentee and Licensee}

We now show that if the patent holder operates one production facility and a licensee operates another, per-unit fixed royalties and fixed fees cannot achieve profit neutrality. Additional license restrictions are required. A positive per-unit royalty is required in order to keep the price up. But that makes the licensee's "effective" marginal cost higher than that of the patent holder. Facing higher costs, the licensee will produce less. Hence the true marginal cost of the last unit produced by the licensee is less than the marginal cost of the last unit produced by the licensor. Costs could be saved by decreasing the licensor's production and increasing the licensee's production. In this sense, the equilibrium does not achieve productive efficiency. 
To see this more formally, let firm 1 and firm 2 be respectively the licensor and licensee. Suppose that the licensee pays (constant) royalty $\rho$. The profit of the licensor, firm 1 , is

$$
p\left(q_{1}+q_{2}\right) q_{1}+\rho q_{2}-\int_{0}^{q_{1}} \gamma(\hat{q}) d \hat{q}
$$

If the licensor takes the licensee's output $q_{2}$ as given, and optimizes with respect to $q_{1}$, his optimal supply satisfies

$$
q_{1}=\frac{1}{2}\left(1-q_{2}-\gamma\left(q_{1}\right)\right)
$$

The profit of the licensee, firm 2 , is

$$
\left(p\left(q_{1}+q_{2}\right)-\rho\right) q_{2}-\int_{0}^{q_{2}} \gamma(\hat{q}) d \hat{q}
$$

If firm 2 takes the licensor's output $q_{1}$ as given, and optimizes with respect to $q_{2}$, the licensee's optimal supply satisfies

$$
q_{2}=\frac{1}{2}\left(1-q_{1}-\gamma\left(q_{2}\right)-\rho\right)
$$

It follows from (3.9) and (3.10) that, in equilibrium,

$$
q_{1}+\gamma\left(q_{1}\right)=q_{2}+\rho+\gamma\left(q_{2}\right)
$$

Since the two firms will not produce the same quantities, the aggregate supply is not produced efficiently at any positive royalty rate. Conditional on (3.11), there may be a royalty rate that supports the price $p\left(q^{*}\right)$, but the licensor will still not receive the maximum profit, due to productive inefficiency.

Another way to see that the licensor and licensee will supply different quantities is to notice that after the royalty agreement is in place, the licensor will want to exploit the licensee. If the licensee supplies half the monopoly output, $q^{*} / 2$, as intended, the royalties and fixed fees that the licensor collects from the licensee are fixed. An 
increase in supply by the licensor will not change them. An increase in supply by the licensor will impose a loss on the licensee through the fall in price, but this is not his concern once the agreement is in place. If the licensor increases supply, the licensor gets all the additional revenue from the increased supply, but bears only half the cost of the fall in price.

The prospect of such ex post opportunism undermines the licensor's ex ante profit. The licensee will rationally predict that, after the license is signed, the licensor will supply more units than the profit-maximizing number of units $q^{*} / 2$, and the market price will be lower than the profit-maximizing price. The licensee realizes that the licensor's ex post supply decision will erode his own profit. The terms that the licensee will accept at the outset will reflect this prediction. As a consequence, the licensor cannot charge the fixed fees that he could charge if he could commit to producing only half the monopoly output, $q^{*} / 2$. This is a subtle point that courts and commentators seem to have overlooked. For example, Bowman (1973) remarks that it "strains credulity" to think that General Electric would adopt a scheme "to restrain its own trade in patented lamps . . ." In fact, this is exactly what General Electric must do to ensure profit neutrality.

Given that per-unit royalties and fixed fees do not achieve profit neutrality, additional license restrictions become necessary. We consider the following candidates:

1. Restricting the licensee's output.

2. Fixing the licensee's price.

3. Imposing a price-matching clause, as in General Electric.

4. Restricting the licensor's own output.

5. Allowing the royalty rate to decrease with the licensee's supply.

6. Allowing the royalty rate to decrease with the licensor's supply. 
We argue that only instruments 1,3 and 6 provide as much profit as the benchmark case.

Output Restrictions. The easiest way to fix the problem is to allow the licensor to cap his own output at $q^{*} / 2$, as part of the license. Such a commitment improves the terms of license that the licensee will agree to, since the licensee is then guaranteed that the market price will be the monopoly price. Since the resulting license would be profit neutral with respect to the benchmark, we see nothing wrong with such a commitment. Courts have held that restricting the licensee's output does not pose an antitrust problem (Weinschel 2000; Hovenkamp, et. al., 2004), but we are unaware of any case where restricting the licensor's output has been challenged.

Price Restrictions. As we have already pointed out, a solution to the incentive problem is for the licensor not to produce at all, and to have two licensees. We now ask whether the General Electric rule can also be a solution when the patent holder has manufacturing capability. The General Electric price-fixing exception allows the licensor to set the price for both the licensor and the licensee.

We should say at the outset that competition is messy when prices can be fixed. A standard notion of competition in the study of oligopolies, also used here, is competition in supply. With the licensing terms in place, each firm makes an independent choice of supply, and the market price then adjusts to ensure that all the units are sold. With price restrictions, that notion must be modified, since prices are not allowed to change endogenously in order to clear the market. For example, if the total supply exceeds demand at the fixed price, then firms will end up with excess supply. This should not happen in equilibrium, but in order to test whether the supply decisions are an equilibrium, we need some notion of how output would be rationed if a firm changed its supply.

For the General Electric price-fixing rule, we will again assume that firms make their supply decisions after the licensing terms have been set. The term of license in General Electric specified that the licensee must charge the same price as the licensor. We interpret the rule to mean that the licensor can set the price at which both firms 
sell. In addition, the agreement may specify royalties and fixed fees. With this agreement in place, the firms choose their supplies.

We claim that the licensor can ensure the monopoly outcome by setting the royalty to be the difference between the profit-maximizing price and the cost of the marginal unit when both firms are producing optimally. That is,

$$
\rho=p\left(q^{*}\right)-\gamma\left(\frac{q^{*}}{2}\right)
$$

The fixed fee must be set so that the licensee's profit is zero if both firms produce $q^{*} / 2$. If we can show that neither firm wants to deviate from half the monopoly supply, $q^{*} / 2$, then the licensor gets all the profit and production is efficient.

We will check whether either firm wants to deviate from the supply $q^{*} / 2$, supposing that $q^{*} / 2$ is the supply of the other firm. Consider first the licensee. The licensee cannot benefit by reducing supply below $q^{*} / 2$. Since each of the inframarginal units provides him with revenue (price) higher than the royalty plus marginal cost, reducing supply will cause him to lose revenue. (Notice that if the price could increase, the licensee would typically want to reduce supply. A reduction would cause the price to increase on all the inframarginal units, while the loss on the marginal unit would be zero.) The licensee also cannot benefit by increasing supply above $q^{*} / 2$. The licensor is also (by hypothesis) supplying $q^{*} / 2$. If the licensee increases supply, the market will have an excess supply at price $p\left(q^{*}\right)$. If the licensee does not manage to sell his marginal units, then he has wasted the cost of producing them. If he does sell them, he cannot cover costs, since the price is not higher than the royalty plus marginal cost of the incremental units. That is, $p\left(q^{*}\right)-(\rho+\gamma(q))<p\left(q^{*}\right)-\left(\rho+\gamma\left(q^{*} / 2\right)\right)=0$ for $q>q^{*} / 2$.

What about the licensor? Will he also be content to supply $q^{*} / 2$ ? Keeping the contractual price fixed at $p\left(q^{*}\right)$, reducing supply will not increase profit, since he gives up profit in amount $p\left(q^{*}\right)-\gamma(q)$ on the marginal units, which is positive for $q \leq q^{*} / 2$. Suppose instead that he increases supply above $q^{*} / 2$. Since the price is fixed at $p\left(q^{*}\right)$, either the marginal unit crowds out a unit that would otherwise be sold 
by the licensee, or the marginal unit is not sold at all. If not sold, it wastes the costs of production. If it crowds out a unit sold by the licensee, then the licensor loses the royalty $\rho$ on that unit. But using (3.12) and the fact that $\gamma(\cdot)$ is increasing, it follows that $\rho>p\left(q^{*}\right)-\gamma(q)$ for $q>q^{*} / 2$; hence the licensor prefers to collect the royalty from the licensee than to crowd out that unit and produce it himself.

This proves that with the license terms specified - a royalty that satisfies (3.12) and price fixed at $p\left(q^{*}\right)$ - there is an equilibrium with profit-maximizing production, even though the licensor competes with the licensee. The licensor can collect all the profit through fixed fees and royalties. ${ }^{7}$

This analysis differs from that of Landes and Posner (2003) who argue that price fixing only serves "to increase the total costs of manufacture, to the detriment of the patentee qua patentee," or Baxter (1966) who argues that price and output restraints are counterproductive because they allow licensees to share in oligopoly profit. Licensors can recover profits by charging fixed fees as well as royalties.

After eighty years of court decisions and commentary, we have come to a striking conclusion: The General Electric Company endorsed one of the few rules capable of implementing profit neutrality. Its solution was also "minimalist." We argue in the appendix (section 8.1) that General Electric could not have achieved the same result by fixing only the price of the licensee.

Nonlinear Royalties. Our final scheme is to consider nonlinear royalties. Of course constant royalties and fixed fees are a form of nonlinear royalty, but payments of

\footnotetext{
${ }^{7} \mathrm{~A}$ slight embarrassment, however, is that, depending on how excess supply is rationed, there can be other equilibria with the property that $q_{1}+q_{2}=q^{*}$ (where $q_{1}, q_{2}$ are respectively the supplied quantities of the licensor and licensee), and $q_{2}<q^{*} / 2$. Even if such an equilibrium exists, it will not be preferred by either party to the equilibrium in which the firms supply $q_{1}=q_{2}=q^{*} / 2$. By moving to the equilibrium with equal ouputs, the licensee benefits because the price he receives on the additional units is larger than the royalty plus marginal cost. The licensor benefits because the royalty he receives on the units transferred to the licensee is larger than the price net of costs of his own supply. In economic games with two equilibria, where both parties prefer one equilibrium to the other, it is easy to ensure that the better equilibrium is played. One of the players can simply announce that he intends to play his strategy in the preferred equilibrium, and the other player will follow. No commitments or license terms are required to implement this outcome. It is self-enforcing.
} 
this form will not guarantee profit neutrality when the licensor and licensee compete.

As we showed above, the licensor can profit by committing himself not to expand output beyond $q_{1}=q^{*} / 2$ once the license is in place. His incentive to expand output follows from the fact that he earns royalties on the licensee's output in any case, and can earn even more profit by expanding the market. Even though his expansion reduces the market price, the licensee bears half of that loss, while the licensor continues to collect royalties, and also sells the additional units. The problem is that, since the licensee can predict this outcome, he will not sign a license agreement in the first place that provides monopoly profit to the licensor. Thus, the licensor can do better by committing not to expand output once the license is in place.

Suppose that instead of imposing a fixed royalty, the licensor imposes a royalty rate $\rho$ that falls with his own output. The fall in royalty rate will punish the licensor for expanding output, and thus creates a commitment not to do so. This will solve the problem. In particular, let $\rho$ be the following decreasing function of $q_{1}$ :

$$
\rho\left(q_{1}\right)=q^{*}-q_{1}
$$

Then $\rho\left(q^{*} / 2\right)=q^{*} / 2$ and $\rho^{\prime}(\cdot)=-1$. The higher the licensor's output, the less royalty he gets, and this will commit him not to increase output beyond $q^{*} / 2$.

Firm 1's profit is

$$
p\left(q_{1}+q_{2}\right) q_{1}+\rho\left(q_{1}\right) q_{2}-\int_{0}^{q_{1}} \gamma(\hat{q}) d \hat{q}
$$

and the optimal supply $q_{1}$, conditional on firm 2's supply $q_{2}$, satisfies

$$
q_{1}=\frac{1}{2}\left(1-q_{2}+\rho^{\prime}\left(q_{1}\right) q_{2}-\gamma\left(q_{1}\right)\right)
$$

Firm 2's profit is

$$
\left(p\left(q_{1}+q_{2}\right)-\rho\left(q_{1}\right)\right) q_{2}-\int_{0}^{q_{2}} \gamma(\hat{q}) d \hat{q}
$$


and firm 2's optimal supply $q_{2}$, conditional on firm 1's supply $q_{1}$, satisfies

$$
q_{2}=\frac{1}{2}\left(1-q_{1}-\gamma\left(q_{2}\right)-\rho\left(q_{1}\right)\right)
$$

At $\left(q_{1}, q_{2}\right)=\left(q^{*} / 2, q^{*} / 2\right)$, neither firm has an incentive to deviate.

Of course this scheme requires that the licensor send a royalty bill to the licensee based on the licensor's own output. It might create an enforcement nightmare for the licensee. The licensor will always want to argue that his supply was lower than it was, and the licensee will want to argue that it was higher.

Nonlinear royalties based on the licensee's supply are common, and at least two courts have said that such agreements do not violate the antitrust laws (Stockham Valves 1966; du Pont 1953). However, in the model presented here, royalties that increase or decrease with the licensee's supply will not lead to profit neutrality because they do not punish the licensor for trying to exploit the licensee once the terms of license are fixed. To punish the licensor for increasing supply beyond that to which he would like to commit, the royalty must depend on the licensor's supply, not the licensee's supply. William Baxter (1966) has previously analysed the role that sliding scale royalties play in partitioning the market between two licensees, but did not consider the case where a patent holder/manufacturer is substituted for one of the licensees.

This is a good place to return to our inquiry about minimalism. The point of stipulating royalties that decline with the licensor's output is to soften the competition that the licensor provides to the licensee. It is even more direct to write license terms that restrict the licensor's supply. Many commentators believe, on somewhat slender case law, that U.S. law permits patent holders to impose minimum output levels on their licensees (Weinschel 2000; Hovenkamp, et al., 2004), but we know of no cases in which a licensor's commitment to self-restraint has been at issue. 


\section{Licensing Patents on Enhancements}

The Supreme Court has also considered cases where rightholders used price-fixing restrictions while licensing a patented enhancement to an existing product. For example, in Ethyl Gasoline the patent holder had the rights to an additive (tetraethyl lead) that raised the gasoline's octane rating. Licensed refiners were not allowed to sell gasoline containing the additive to unlicensed middlemen ("jobbers") and jobbers who failed to observe the major refineries' posted prices were regularly terminated for displaying poor "business ethics." The net effect was to set the price at which licensed jobbers could sell high-performance gasoline. The court struck down the jobbers' licenses on the ground that they violated the antitrust laws.

In Line Material, Southern States Equipment Corporation held a patent on an electrical fuse, and Line Material held a patent on an improvement. A patent interference proceeding established that Line Material's improvement infringed the Southern patent, so that neither firm could market the improvement without a license from the other. We will argue that the three principles should apply differently to this situation of blocking patents than to the case of a patented enhancement to an unpatented good as in Ethyl, or to the case of a noninfringing enhancement to a patented good, for which we have not found a useful motivating case.

We see no evidence in these cases that the courts disagree with our three principles, although we will argue that the economic analysis in Line Material is defective and led the court to the wrong conclusion. The court struck down a cross license with price-fixing. As discussed below, we think that for blocking patents, cross-licensing is justified by the derived-reward principle, and price-fixing may be necessary to remedy a problem of productive efficiency, just as in General Electric. Except for the narrow problem of productive efficiency that was addressed by allowing price-fixing in General Electric, we find no further justification for price-fixing in the circumstance of blocking patents.

In considering proprietary enhancements to existing goods, we will assume that 
each consumer's willingness to pay for the enhanced product is larger than for the original product by amount $\Delta$. Applying the derived-reward principle, the inventor should not receive more than $\Delta$ per unit sold.

As before, we will suppose that the demand for the underlying good, say, unenhanced gasoline, is given by a function $1-p$, where $p$ is the price, and that the inverse demand curve is therefore given by $1-q$. Suppose that the marginal cost of a unit of unenhanced gasoline is $c \leq 1$. Then the demand for enhanced gasoline at price $p$ is $1+\Delta-p$, and the willingness to pay for the $q^{\text {th }}$ unit (the inverse demand curve) becomes $p(q)=1+\Delta-q$.

We will not yet make a distinction between selling the additive at a proprietary price or licensing the right to produce gasoline that includes the additive. In both cases, we will refer to the price or royalty as $\rho$.

We now consider, respectively, proprietary enhancements to competitively supplied goods, proprietary enhancements to proprietary goods, and infringing enhancements to proprietary goods. We argue that one-way licensing with royalties is consistent with our principles in the first two cases, and that cross-licensing with two-way royalties is consistent with our principles in the third case. Price fixing may also be consistent with our principles if there is an issue of productive efficiency.

Patented Enhancements to Competitively Supplied Goods. Assume for simplicity that the resource cost of producing the enhancement (gasoline additive) is zero, and the unit cost of producing the competitively supplied product (gasoline), whether enhanced or unenhanced, is $c$. In a competitive market, the cost of enhanced gasoline will then be $p=c+\rho$ if $\rho$ is the wholesale price of the additive or the royalty for adding it to the gasoline. If the licensor charges the entire value as royalty, $\rho=\Delta$, the price of gasoline will go up by $\Delta$, so that sales of the enhanced gasoline are the same as without the additive. During the life of the patent, it is the patent holder rather than user who collects the social value. This is consistent with the derived-reward principle that the profit must derive from the social value. 
We now show that either $\Delta$ is so large that it drives out the competitive product, or the licensor's optimal royalty is $\rho=\Delta$.

If there were no competitive supply of the unenhanced product, the monopolist proprietor of the enhancement would choose the supply $q$ that maximizes

$$
(1+\Delta-q-c) q
$$

The parenthetic term is the sales price when $q$ units of enhanced gasoline are supplied. The profit-maximizing quantity of enhanced gasoline satisfies

$$
q^{*}(\Delta)=\frac{1}{2}(1+\Delta-c)
$$

and the corresponding monopoly price is

$$
p\left(q^{*}(\Delta)\right)=1+\Delta-q^{*}(\Delta)=\frac{1}{2}(1+\Delta+c)
$$

If the improvement is large, $\Delta>1-c$, and the improver charges the monopoly price, then suppliers of the inferior product will drop out of the market even without licensing. The case of interest is when the proprietor will have to license to the competitive suppliers because they will not disappear. This will occur for small improvements, $\Delta<1-c$. No distributor would buy the additive at a price greater than $\rho=\Delta$, so $0<\rho \leq \Delta$. The licensor's profit is $\rho(1+\Delta-\rho-c)$, which is maximized at $\Delta=\rho$ when $1-c>\Delta$. Thus, the licensor will charge a price or royalty equal to the full value of the additive, and only the enhanced gasoline will be supplied.

Consistent with these observations, it seems clear under the derived-reward principle that the licensor should be allowed to profit in amount $\Delta$ per unit of gasoline sold, but not more. This is true even if gasoline suppliers operate as oligopolists in the distribution of gasoline, rather than as perfect competitors, as discussed in the appendix, section 8.2. However, the analysis disagrees with Baxter (1966) who argues that all royalties on the sale of unpatented end-products should be banned because they allow patent holders to "drain off the full monopoly potential inherent not in 
the invention but in the unpatented end product of which the invention is only one of many inputs." As long as the competitive gasoline suppliers are free to sell unenhanced gasoline, the gasoline market will not be monopolized. The price of gasoline will only be higher by the value of the enhancement, $\Delta$.

Of course, the most profitable arrangement is to keep unenhanced gasoline off the market and sell enhanced gasoline at the monopoly price (4.2) even when $\Delta$ is relatively small so that without sham licensing the royalty would be $\Delta=\rho$. The following license terms will support the monopoly price, provided all the gasoline distributors take the license.

(a) Charge a royalty $\rho=p\left(q^{*}(\Delta)\right)-c$ for producing and using the additive, stipulating that licensees cannot avoid the royalty by selling the unenhanced gasoline. Share the profit through fixed fees.

(b) Charge a fixed fee for producing and using the additive, stipulating that the price of enhanced gasoline must be $p\left(q^{*}(\Delta)\right)$, and stipulating that the licensees cannot sell unenhanced gasoline. Share the profit through fixed fees.

To support the monopoly price, a sham license must either stipulate that the licensee will pay royalties on unenhanced gasoline as well as enhanced gasoline, as in (a), or that the licensee will sell only enhanced gasoline, as in (b). Without being bound in one of those ways, a licensee can profit by selling unenhanced gasoline at a price between the marginal cost $c$ and the monopoly price $p\left(q^{*}(\Delta)\right)$. That will break the cartel. Because the license terms in (a) and (b) will support a cartel, they should not be allowed.

Of course, entry will also break the cartel. If there is always a threat of entry by an unlicensed entrant, the market price for unenhanced gasoline must be $p=c$, and the price of enhanced gasoline can be no greater than $c+\Delta$. Higher prices will elicit entry.

The reader will have no trouble seeing that cost reductions can be analyzed in the same way as product enhancements. Instead of adding to the product's value, 
suppose the innovation reduces the cost of manufacturing it. Whether $\Delta$ is conceived as a boost to the consumer's willingness to pay for the product or a reduction in the cost of manufacturing it, the innovation would increase the consumers' surplus available in a competitive market by $\Delta$ per unit. For reasons analogous to the ones given here, allowing the licensor to fix prices would allow him to profit from cartelization instead of from the social value he created, in violation of the derived-reward principle. Instruments to fix the monopoly price will take the same forms as above, i.e., binding the licensees to pay royalties regardless of whether they use the patented innovation, or specifying the price they must charge while preventing them from reverting to the inferior product.

We conclude that in the case of patented enhancements to unpatented goods, and also in the case of cost reductions, royalties are a rich enough licensing instrument to collect the profit that Congress intended. Price-setting power is not only unnecessary, but could allow the licensor to cartelize the market, thus earning profit from a source (the cartel) not created by the invention. This violates the derived-rewards principle.

Patented Enhancements to Patented Goods: One-Way Licensing. In the previous section we supposed that the original good (e.g., gasoline) was supplied in an unprotected market. We shall now assume that the previous good is itself proprietary. In this section we assume that the enhanced good does not infringe the previous patent, and in the next section we assume that it does.

If the two proprietary goods are noninfringing, is there any reason to allow licensing at all? One reason would be to achieve productive efficiency, as in the case of product patents discussed in section 3. Our focus here is on another type of efficiency. Without licensing, one of the proprietors would supply an inferior product, even if the marginal cost of producing both products is zero. Depending on prices, consumers may be better off if both firms supply the better product. What licensing terms, if any, should be allowed in order to achieve this result, without undermining the competition between the patent holders that Congress apparently intended? 
Suppose, for example, that the two firms write a licensing agreement that commits the proprietor of the inferior product, whom we shall call firm 1, to stay out of the market. Then the proprietor of the enhanced product, whom we shall call firm 2 , becomes a monopolist. This is presumably the most profitable arrangement for the two firms, and the proprietor of the better good should be willing to pay his potential competitor to stay out. Most commentators would agree that such an arrangement would be collusive, but how does that follow from the principles we have articulated? What licensing terms are consistent with our principles? Can the allowable licensing terms ensure that only the better product is supplied, while at the same time avoiding the collusive outcome?

We claim that the only licensing arrangement consistent with the derivedreward principle is a license from firm 1 to firm 2, giving the right to produce the enhanced product in return for royalties and perhaps other fees A license from firm 2 to firm 1 is not consistent with that principle, since firm 1 has nothing of value to offer firm 2. Cross-licensing is not consistent with the derived-reward principle. Further, we show that the one-way license will not allow the firms to cartelize the market. Despite the license, the price of the enhanced product will be constrained by potential competition from the inferior product.

To make our case, we need to characterize the outcomes of three market arrangements: that the patent holders compete without a license, that firm 2 licenses to firm 1 with royalties and perhaps fixed fees, and that the firms find a way to support the collusive outcome. We will show that the first two arrangements are equivalent for consumers, but the second arrangement, one-way licensing, is more profitable for the firms. (There is an efficiency gain, and the value accrues to the firms.) The collusive outcome is more profitable still, but imposes the monopoly price on consumers. Thus, one-way licensing achieves the objective of economic efficiency (all consumers consume the better good), while avoiding the collusive outcome. That is, the licensing terms that seem to follow naturally from the derived-reward principle also lead to the desired outcome. The inferior product is kept off the market, but the firms still compete in 
a limited way that falls short of collusion. ${ }^{8}$

Let $p^{I}$ be the price of the original, inferior good, and let $p$ be the price of the enhanced good. Then, since each user has willingness to pay $\Delta$ for the enhancement, prices must satisfy

$$
p^{I}=\max \{0, p-\Delta\}
$$

With these prices, the demand for units of both products is the same as if both firms supplied the enhanced product at price $p$. That is, the number of units demanded is $1+\Delta-p$, but some of the units will be the inferior product, which provides less utility in amount $\Delta$ and sells at a price $p^{I}$ that is lower by $\Delta$. For simpler calculations, and because our focus is not on productive efficiency, we will now assume that the marginal cost of production is zero.

We will first characterize the equilibrium prices without licensing. In evaluating its profit opportunities, firm 1 takes as given firm 2's supply of the enhanced good, $q_{2}$. Firm 1's profit as a function of its own supply of the inferior good, $q$, is

$$
\left(1-q-q_{2}\right) q
$$

and the profit-maximizing quantity satisfies

$$
q=\frac{1}{2}\left(1-q_{2}\right)
$$

Similarly, firm 2's profit is

$$
\left(1+\Delta-q-q_{2}\right) q_{2}
$$

\footnotetext{
${ }^{8}$ The proprietor of the inferior product might argue that these licensing provisions erode his profits to the point where he can no longer cover the costs of innovation. If the argument has merit, it is due to a failing of patent law instead of competition policy. Making the patents blocking instead of noninfringing would allow both inventors to profit from their innovations. See the next section and chapter 5 of Scotchmer 2005 for a more systematic discussion of design issues in the context of cumulative innovation.
} 
and its profit-maximizing supply satisfies

$$
q_{2}=\frac{1}{2}(1+\Delta-q)
$$

The equilibrium quantities $\left(q, q_{2}\right)$ solve (4.5) and (4.7), namely,

$$
\begin{aligned}
q & =\frac{1}{3}(1-\Delta) \\
q_{2} & =\frac{1}{3}(1+2 \Delta)
\end{aligned}
$$

and therefore the prices are

$$
\begin{aligned}
p^{I} & =\frac{1}{3}(1-\Delta) \\
p & =\frac{1}{3}(1+2 \Delta)
\end{aligned}
$$

We will now show that the second market arrangement, licensing from firm 2 to firm 1 , is equivalent for consumers to competition without licensing, and better for the patent holders. The largest royalty, $\rho$, that would be offered or accepted is $\rho=\Delta$. At a larger royalty, firm 1 would supply the inferior good rather than the enhanced good under license. The constraint $\rho \leq \Delta$ is the key ingredient to our conclusion that licensing creates benefits for patent holders without harming consumers.

In evaluating its profit opportunities, the licensee, firm 1, again takes as given firm 2's supply of the enhanced good, $q_{2}$. Firm 1's profit as a function of its own supply of the enhanced good, $q_{1}$, is

$$
\left(1+\Delta-q_{1}-q_{2}-\rho\right) q_{1}
$$

and the profit-maximizing quantity satisfies

$$
q_{1}=\frac{1}{2}\left(1+\Delta-q_{2}-\rho\right)
$$

Similarly, firm 2's profit-maximizing supply satisfies

$$
q_{2}=\frac{1}{2}\left(1+\Delta-q_{1}\right)
$$


The equilibrium quantitites $\left(q_{1}, q_{2}\right)$ solve (4.9) and (4.10), namely,

$$
\begin{aligned}
& q_{1}=\frac{1}{3}(1+\Delta-2 \rho) \\
& q_{2}=\frac{1}{3}(1+\Delta+\rho)
\end{aligned}
$$

Therefore the price will be

$$
\frac{1}{3}(1+\Delta+\rho)
$$

Total output of the enhanced good will be

$$
\frac{1}{3}(2(1+\Delta)-\rho)
$$

The sum of the two firms' profit is

$$
\frac{1}{9}(1+\Delta+\rho)(2(1+\Delta)-\rho)=\frac{1}{9}\left(2(1+\Delta)^{2}+\rho(1+\Delta)-\rho^{2}\right)
$$

Since the firms can divide the joint profit with fixed fees, they want to maximize joint profit. The joint profit is greatest at $\rho=\Delta$. Therefore the price of the enhanced good is the same with and without licensing, namely $(1 / 3)(1+2 \Delta)$. This accounts for our claim that consumers are as well off with licensing as without. However, the firms' joint profit with licensing is

$$
\frac{1}{9}\left(2(1+\Delta)^{2}+\Delta\right)
$$

which is larger than their profit in competition with each other, in the absence of a license.

We now compare this result to the collusive outcome in which firm 1 renounces its right to supply the inferior product. The monopoly price and quantity of the enhanced good satisfy (4.2) and (4.1) with $c=0$, and the maximum profit is

$$
\frac{1}{4}\left((1+\Delta)^{2}\right)
$$


The collusive profit (4.13) is larger than the profit (4.12) available with one-way licensing, and the price of the enhanced good is also higher, $\frac{1}{2}(1+\Delta)>(1 / 3)(1+2 \Delta)$, in the case $(\Delta<1)$ where the possibility of supplying the inferior good is actually a constraint in the market.

We conclude that the one-way license allows the proprietor to profit from the social value of the enhancement without profiting from cartelizing the market. This is the only type of license that should be allowed under our principles. In contrast, a cross-license of the type discussed in the next section would allow the two firms to earn monopoly profits as if the proprietor of the enhancement created the whole market.

Blocking Patents on Enhancements: Cross Licensing. We continue using the same model, but now assume that the enhanced product infringes the patent on the original product, so the patent holders have blocking patents. This was the situation in Line Material (1948). Since the enhanced product infringes the patent on the inferior product, the knowledge created by the first innovator was presumptively required to develop it. In this sense, the net value of the enhanced product is presumptively part of the social value created by the first innovator, even though the second innovator bore the incremental costs (Scotchmer 1991). By the derived-reward principle, the first innovator is entitled to profit from it.

There are not many possibilities for how to resolve the blocking patents so that the enhanced product can come to market. They include:

(a) Consolidate ownership of the patents (one patent holder sells to the other).

(b) Allow the patent holders to cross license the enhanced product, each paying royalties to the other.

(c) Allow the patent holders to cross license with royalties, fixing the price of the enhanced good, and stipulating that the inferior good will not compete in the market.

(d) Force the patent holders to cross license without royalties. 
We assume that (d) is not what Congress had in mind, as it leads to the same market outcome as if the patents were not blocking, discussed in section $4.2 .{ }^{9}$ It is easy to see that (c) is equivalent to (a). We now show that (b) is also equivalent to (a), provided that the cost of manufacturing the enhanced good is the same regardless of how the manufacturing is divided between the firms. However, echoing our discussion of section 3, (b) is not equivalent to (a) or (c) if the manufacturing must be divided in a particular way to achieve cost efficiencies.

Since the enhancement adds $\Delta$ to every user's willingness to pay, the inverse demand curve can again be written as $p(q)=1+\Delta-q$, where $q$ is the quantity supplied of the enhanced good, and the inferior good is not supplied. The most profitable arrangement is for only the better product to be produced. ${ }^{10}$ We will first assume that the marginal cost of producing both goods is the same, and for simplicity, equal to zero. Then any manufacturing arrangement is equally cost-efficient.

Clearly the maximum profit can be achieved if both patented goods are owned or controlled by a single firm (solutions (a) and (c)). What we will now show is that it can also be achieved by cross licensing with royalties (solution (b)), but only if the previous patent holder, whom we again call firm 1, can either renounce his right to supply the inferior product, or pays a low enough royalty that he has no incentive to supply it.

Assume that the cross license on the enhanced good provides for royalties in amounts $\left(\rho_{1}, \rho_{2}\right)$, with firm 1 charging a royalty $\rho_{2}$ to firm 2 and firm 2 charging a royalty $\rho_{1}$ to firm 1 . We will show that in order to sustain the profit maximizing price,

\footnotetext{
${ }^{9}$ Although this seems self-evident to us, Line Material (1948) seems to assume that the economic consequences of blocking and nonblocking patents are the same: "Where two or more patentees with competitive, noninfringing patents combine them and fix prices on all devices produced under any of the patents, competition is impeded to a greater degree than where a single patentee fixes prices for his licensees. The struggle for profit is less acute. Even when, as here, the devices are not commercially competitive because the subservient patent cannot be practiced without consent of the dominant, the statement holds good. The stimulus to seek competitive inventions is reduced by the mutually advantageous price-fixing arrangement." We argue here that the two situations are economically distinct. See chapter 5 of Scotchmer 2005 for a more extensive discussion of how the incentive effects depend on whether the successive patents are noninfringing.

${ }^{10}$ If users value the enhancement differently, both products might survive in the market, allowing a sort of price discrimination. See Gabscewicz and Thisse (1980).
} 
these royalties must satisfy

$$
\begin{aligned}
& \rho_{1}+\rho_{2}=\frac{1}{2}(1+\Delta) \\
& \rho_{1} \leq \Delta
\end{aligned}
$$

The constraint (4.15) on $\rho_{1}$ is needed to dissuade firm 1 from undercutting the market by supplying the inferior product as well. However the constraint imposes no harm provided the cost of aggregate supply does not depend on how the supply is divided between the firms. That is, it imposes no harm if there is no issue of productive efficiency.

With the royalties in place, and assuming that firm 1 does not supply the inferior good, the firms will choose their most profitable supplies, $\left(q_{1}, q_{2}\right)$, realizing that the price in the market will satisfy

$$
p\left(q_{1}+q_{2}\right)=1+\Delta-q_{1}-q_{2}
$$

Taking as given the royalties $\left(\rho_{1}, \rho_{2}\right)$ and the supply $q_{2}$ of firm 2 , firm 1's profit function is

$$
\left(p\left(q_{1}+q_{2}\right)-\rho_{1}\right) q_{1}=\left(1+\Delta-q_{1}-q_{2}-\rho_{1}\right) q_{1}
$$

and the profit-maximizing quantity satisfies

$$
q_{1}=\frac{1}{2}\left(1+\Delta-q_{2}-\rho_{1}\right)
$$

Similarly, firm 2's profit-maximizing quantity satisfies

$$
q_{2}=\frac{1}{2}\left(1+\Delta-q_{1}-\rho_{2}\right)
$$

Adding (4.17) and (4.18), it follows that the aggregate equilibrium supply $q_{1}+q_{2}$ satisfies

$$
q_{1}+q_{2}=\frac{2}{3}(1+\Delta)-\frac{1}{3}\left(\rho_{1}+\rho_{2}\right)
$$


But since the objective is to choose the royalties such that the equilibrium quantities satisfy

$$
q_{1}+q_{2}=q^{*}(\Delta)=\frac{1}{2}(1+\Delta)
$$

condition (4.14) must hold. The royalty $\rho_{1}$ paid by firm 1 cannot be higher than $\Delta$ without leading to the result that firm 1 supplies the inferior good instead of the enhanced good. Each $\rho_{1} \in[0, \Delta]$ (and $\rho_{2}$ chosen to satisfy (4.14)) implies a different division of profit, not accounting for fixed fees. Thus, if the two firms have the same constant marginal cost of supply, there is a cross licensing arrangement that sustains the maximum profit. In this arrangement,

- each firm pays a royalty to the other on the enhanced units it sells;

- the royalty paid by the previous patent holder is positive, but may be smaller than the royalty paid by the improver;

- the previous patent holder has no incentive to undermine the monopoly on the enhanced product by selling the inferior product;

- the profits can be divided arbitrarily by using fixed fees as well as royalties.

We thus conclude that when manufacturing costs are the same regardless of which firm supplies the market, a cross-licensing agreement is profit neutral with respect to the benchmark solution (a) where the patent holders are allowed to consolidate their patent rights. By the minimalist principle, there is no need to allow price fixing. The decision against price-fixing in Line Material may therefore be consistent with our principles, even though the reasoning in the case is, in our view, misguided (see footnote 10).

The conclusion changes, however, if each firm's marginal cost of production is increasing, or if the firms have different marginal costs of production. In that case there is an issue of productive efficiency as in section 3, so royalties and fixed fees are no longer profit neutral. Profits may be higher under solution (a) than (b). 
When productive efficiency is at issue, cross licensing with only royalties and fixed fees may result in one of the following problems.

1. Manufacturing costs are unnecessarily high due to unequal production in the firms, so that the firms earn less than maximum profit.

2. Manufacturing is efficient, but the firms earn less than the maximum profit because royalties are too low.

3. The firms earn less than the maximum profit because the inferior product is also supplied to the market.

To see this more formally, modify the above model so that the marginal costs of manufacturing are given by a function $\gamma(\cdot)$, as in section 3 above, and for simplicity, assume that these are the costs in each firm. Then the maximum profit is

$$
p\left(q^{*}(\Delta)\right) q^{*}(\Delta)-2 \int_{0}^{q^{*}(\Delta) / 2} \gamma(z) d z
$$

where the optimal quantity and price satisfy

$$
\begin{aligned}
q^{*}(\Delta) & =\frac{1}{2}\left(1+\Delta-\gamma\left(\frac{q^{*}(\Delta)}{2}\right)\right) \\
p\left(q^{*}(\Delta)\right) & =1+\Delta-q^{*}(\Delta)
\end{aligned}
$$

The optimum clearly requires equal production in the two firms. To support equal production, the royalties must be equal, $\rho_{1}=\rho_{2}$. In the appendix (section 8.3), we show that the royalties required to support the profit maximizing price are

$$
\rho_{1}=\rho_{2}=\frac{1}{4}(1+\Delta)-\frac{1}{4} \gamma\left(\frac{q^{*}(\Delta)}{2}\right)
$$

However, if $\rho_{2}=\rho_{1}>\Delta$, these will not sustain the profit maximum, since firm 1 will supply the inferior product instead of the enhanced product, thus depriving firm 2 of royalties. The condition (4.21) may be inconsistent with $\rho_{2}=\rho_{1} \leq \Delta$ if $\Delta>1 / 3$ and costs $\gamma$ are relatively low. There are several ways to solve these problems, but 
they may require terms of license beyond cross licensing the enhanced product. Two possibilities are

1. Write into the terms of license that firm 1 will not supply the inferior product, and write royalty rates that satisfy (4.21). Distribute the profit with fixed fees.

2. (Price Fixing) Set the price at $p\left(q^{*}(\Delta)\right)$ and divide the market so that the proprietor of the inferior product gets at least as much profit as it would make by keeping the superior product out of the market.

The neutrality principle suggests that the first solution should be legal - the licensee should be allowed to renounce his right to supply the inferior product - especially if the second solution, price fixing, remains illegal under Line Material.

\section{Possible Per Se Rules}

This section suggests three possible per se rules that follow from the three principles, and discusses some of their advantages and disadvantages. Where the presumption in favor of these rules can be rebutted, we think the rules that replace them should use the three principles as a guide.

1. Patent licenses based on a combination of (positive) fixed fees and per-unit royalties should be presumptively lawful.

2. In cases where the rightholder competes with the licensee, licenses that (a) fix product prices for the licensee and licensor, (b) require the licensee or licensor to observe quantity limits, or (c) reduce the licensee's per unit royalties as licensor output increases should be presumed lawful.

The second rule applies both in the case of licensing product patents and in cross-licensing blocking patents.

These proposed rules require additional comment: 
First, the rules reduce but do not eliminate uncertainty for licensors. They establish presumptions, as do most per se rules created by courts (Areeda \& Hovenkamp, 2003) and commentators (Baxter 1966; Adelman \& Juenger 1975; Kaplow 1984), but presumptions can be challenged. The main danger is that judges may be too wary of sham agreements. Courts had good reason to be suspicious in the days when commentators argued that licensing is a second-best way to exploit a patent, and would ordinarily be avoided by a sensible patent holder (Baxter 1966; Adelman \& Juenger 1975). A more modern view, which undercuts the case for suspicion, is that licenses are efficient and appropriate, even (sometimes) when they fix prices. Thus, courts should normally uphold the presumption that licenses are pro-competitive absent evidence that royalties exceed the value of the defendant's invention or other circumstances that clearly point to collusion. ${ }^{11}$

Second, our conclusions follow from a standard, but nevertheless specific, economic model about how licensors and licensees behave - namely, that they engage in quantity competition. However, the intuition is more robust than our particular model. The productive inefficiency arises because the licensor perceives a lower marginal cost of production than the licensee, and will produce too much relative to the licensee. It is hard to see how any form of competition between the licensor and licensee would change this conclusion as long as marginal cost is increasing. In any case, all per se rules can be rebutted with new and convincing arguments. For a successful rebuttal, a plaintiff would have to produce (a) a model where the effect vanishes, and (b) evidence that the model is more appropriate to the facts than the very standard model discussed in this paper.

Third, more complicated models might render our results ambiguous. For example, some commentators have argued that rightholders cannot use licenses effectively because of limited information about licensees' cost functions, current market demand, and/or future demand (Landes \& Posner 2003; Adelman \& Juenger 1975). ${ }^{12}$

\footnotetext{
${ }^{11}$ Such circumstances might include that the property right is likely invalid or that it can easily be avoided by "inventing around" (Adelman and Juenger, 1975).

${ }^{12}$ To the contrary, Landes \& Posner (2003) invoke these factors as a possible justification for General Electric-style price restrictions. In our view, these disagreements show the need for economic
} 
On the other hand, courts' "inability to find all the relevant facts" is a traditional justification for having per se rules in the first place (Areeda \& Hovenkamp, 2003). Plaintiffs who advance these alternative arguments should produce the evidence or models to justify them, and say how they implement the three principles.

Fourth, our focus on productive efficiency does not exhaust the licensing landscape. Some commentators argue that licensing undermines the incentive to challenge a bad patent, since it creates collusion between otherwise competitors (Landes \& Posner 2003; Adelman \& Juenger 1975; Shapiro 2003; Hovenkamp, Janis, and Lemley, 2004). This argument is not actually about the patent/antitrust boundary, since it goes to the proper functioning of the patent system itself. Scholars also argue that cross licensing should be permitted in cases where it is needed to save transactions costs or suppress wasteful patent races (Landes \& Posner 2003).

Fifth, although the minimalism principle would allow courts to strike down unnecessary restrictions in licenses, it says nothing about whether some other, completely different, bundle of restrictions would impose even fewer burdens on the economy. It may be difficult for judges to compare licenses against practices not before the court (Kaplow 1984). ${ }^{13}$

Sixth, many commentators think the main defect of per se rules as compared to rule of reason is that per se rules eliminate a court's ability to fine-tune patent rewards based on cost of development. However such fine-tuning might be too difficult in practice (Kaplow 1984). More importantly, Congress has created a one-size-fits-all patent system, and it is the job of Congress, not the job of courts, to improve on it.

\section{Rule of Reason}

In general, rule of reason and per se rules like the one stated in General Electric lead to different outcomes. Rule of reason permits the court to treat a given license term

modeling.

${ }^{13}$ Similarly, a court might have no occasion to rule that a restriction is superfluous unless the restriction has an anticompetitive effect. This limits the opportunities to strike down such terms. 
differently in different circumstances. Rule of reason seems tautologically better, since a court can always choose to follow the per se rule except where improvement seems possible. However, this overlooks the difficulty of finding and implementing principles to define such improvements. Here, we discuss what rule of reason might mean in the patent-antitrust context.

In practice, rule of reason is seldom based on a complete, well-articulated principle. ${ }^{14}$ The most ambitious attempt to enunciate principles is due to Kaplow (1984). He argues that Congress implicitly encoded its judgment about the optimal balance of ex ante and ex post efficiency when it designed the patent statute. A licensing restriction should be acceptable to the court if it generates a profit-todeadweight-loss ratio larger than that which Congress implicitly accepted in defining, for example, breadth or patent life. This procedure saves the court from having to decide how much reward an innovator should receive, at least directly. The optimal reward is implicitly established in the profit-to-deadweight-loss ratio. ${ }^{15}$

Kaplow concedes that any practical application of the ratio test is "quite complex." Given that the required information "will not generally be available," court decisions "must inevitably be speculative." 16 He concludes that "any careful attempt to resolve patent-antitrust issues will be far more complex than has previously been realized" and that fact reveals the "insufficiency of prior formulations by courts and commentators." Scholars in the past twenty years have done little to change this assessment.

\footnotetext{
${ }^{14}$ For example, the U.S. Department of Justice and Federal Trade Commission say that the benefits of allowing the licensor "to exploit its [intellectual] property as efficiently and effectively as possible," must outweigh the harm to competition (1995 Antitrust Guidelines). The problem with this approach is that it fails to specify how courts should balance ex post deadweight loss against ex ante incentives to innovate.

${ }^{15}$ The most useful approach relies on breadth rather than duration. If markets are stable over time, the profit-to-deadweight-loss ratio is the same for all patent durations. However, the ratio test has been revived by authors studying patent breadth; see chapter 4 of Scotchmer (2005) for a summary.

${ }^{16}$ Kaplow admits that in practice it is probably impossible to estimate Congress's subjective cost/benefit judgment by analyzing the patent statutes. He therefore proposes a less ambitious use of his ratio called cost-effectiveness. This procedure asks judges to reshuffle the law by making currently permitted licenses with low ratios illegal in exchange for legalizing currently prohibited practices with high ratios. Kaplow concedes, however, that even this more modest project may not be possible given current uncertainty about the "economic effects of various restrictive practices."
} 
Any rule-of-reason approach directed at maximizing an aggregate measure of consumer welfare will face the same practical and theoretical difficulties identified by Kaplow. Given Kaplow's pessimistic forecast as to whether the ratio test can be implemented, the more likely approach seems that implied by the 1995 Antitrust Guidelines, requiring judges to weigh de novo the value of rewards (ex ante efficiency) against the value of competition (ex post efficiency) in each case. But this opens up a host of inquiries. Should the court naively determine the necessary reward based on the actual costs of the patent holder? Should the factual inquiry about costs instead consider that some other inventor could have achieved the patent more cheaply, and that too much reward only encourages waste? Should the inquiry consider that research is risky, and that a discoverer would only have invested if he expected a super-reward for success? Given that the research endeavor was eventually successful, what evidence could be adduced to show that it might not have been, and with what probability?

The ways that such an inquiry can go astray are almost endless, as noted by other commentators. First, the factual inquiry is so complex as to be unavoidably speculative, and may defer to ideological prejudice. Baxter (1966) argues that the weighing of proper rewards is "peculiarly appropriate" to the political branches of government. ${ }^{17}$ Of course, one can argue that judges' opinions do not matter provided that Congress can easily correct them. In practice, most judicial attempts to weigh ex ante and ex post efficiency will never be reviewed, much less corrected.

Second, any such inquiry requires specialized knowledge, and is likely to be lengthy and complex. Landes and Posner (2003) argue that the ex ante/ex post tradeoff "may well be beyond the capacity of the courts." Kaplow (1984) is more optimistic, observing that the required analysis "is probably more developed at both the theoretical and empirical levels than is the analysis of a vast array of other issues that the courts regularly confront."

\footnotetext{
${ }^{17}$ Balancing innovation against ex post deadweight loss also requires normative judgments about intergenerational transfers. Judges have no objective standards for deciding "whether, in any given case, it would be desirable to sacrifice more or less consumer satisfaction of other wants by devoting more or fewer resources to the promotion of innovation." (Bork 1965)
} 
Third, the inquiry will almost always depend on parties and evidence not before the court. Except when the government is a party or citizens file amicus briefs, the interests of third parties will almost always be underrepresented. However, there is reason to suspect that many patent agreements derive their value "precisely because [they] are injurious to third persons." (Baxter 1966) The temptation to impose costs on third parties - who are seldom in a position to know, let alone complain - may be overwhelming.

Fourth, permitting judges to set the balance each time they decide a case will inevitably make patent rewards less certain (Bork 1977; Adelman \& Juenger 1975). Inventors will demand a larger reward - with greater attendant deadweight loss - for any given level of inventive effort (Gifford 2002).

Fifth, courts almost always examine controversies ex post whereas legislatures and executive agencies tend to make policy ex ante. Since the particular innovation before the court cannot be un-invented, there may be a built-in bias toward addressing antitrust issues at the expense of innovation. More broadly, judges may conclude that their judgment in a single case cannot possibly affect innovation in the broader society. Nevertheless, the aggregate effect of court decisions will likely be substantial.

\section{Conclusion}

Subsequent case law has made the General Electric price-fixing exception quite narrow. Critics have therefore argued that the price-fixing exception is a discredited "vestige." We disagree. Based on the analysis above, a narrow price-fixing exception is exactly what is required by the three principles of derived-reward, profit-neutrality, and minimalism. Licensing terms that are more restrictive than royalties and fixed fees are only justified where a licensor and licensee compete with one another, including where they cross license blocking patents.

Our analysis based on the three principles is more favorable to per se rules than is currently the fashion. The alternative, rule of reason, must be applied with some 
well-articulated objective in mind. One problem is that there is no consensus on the right objective, and another is that the main proposals are hard to implement on the basis of facts likely to be before a court. Consequently, rule of reason gives scope for unpredictability in outcomes, which creates uncertainty for patent holders and reduces Congress's control over patent incentives. Uncertainty can chill patent holders' willingness to write creative license terms, even when justified, and consequently can chill their ability to exploit patented knowledge. On the positive side, rule of reason lets judges tailor rewards to individual circumstances. However, the required inquiry is so inherently speculative that flexibility may not lead to any net improvement.

We do not suggest that our three principles will give guidance in every licensing situation. But where they apply, such as in the core patent/antitrust cases of the twentieth century that we have discussed, they reduce the inquiry to a simple economic question. Courts may occasionally have stumbled over the economics, but their approach to licensing, which we interpret to be based on our three principles, seems sound.

\section{Appendix:}

\subsection{Fixing a Licensee's Price, but not the Licensor's Price}

We showed in section 3.1 that General Electric restores profit neutrality by fixing the licensee's price to match the licensor's price. Here we show that it is not enough simply to specify a price for the licensee, without committing the licensor to the same price.

To support the monopoly profit, the stipulated price will have to be $p\left(q^{*}\right)$, and the equilibrium supplies will have to be $q_{1}=q_{2}=q^{*} / 2$. Supposing that $q_{2}=q^{*} / 2$ the royalty must be (3.12) in order to ensure that $q_{1}=q^{*} / 2$. Then, since the licensee cannot charge a price higher than $p\left(q^{*}\right)$, he has no incentive to cut supply in order to raise the market price. And he has no incentive to increase supply, since he would then pay more in royalties and costs than the price of the marginal unit. Thus, the 
price-fix will ensure that the licensee supplies the optimal quantity, $q^{*} / 2$.

However, this regime gives licensor an incentive to opportunistically increase supply beyond $q^{*} / 2$, and thus profit at the licensee's expense.

Defining the licensor's profit function will now be a little trickier because of the out-of-equilibrium rationing problem. To test whether $q_{1}=q_{2}=q^{*} / 2$ is an equilibrium, the licensor must hypothesize what will happen if he increases or decreases his own supply. If he deviates in supply, there will be two prices in the market. If the licensor cuts supply, so that aggregate supply is less than $q^{*}$, the licensor's supply price will be higher than $p\left(q^{*}\right)$, while the licensee's price is fixed at $p\left(q^{*}\right)$. If the licensor increases supply, his supply will be sold at a price lower than $p\left(q^{*}\right)$, while the licensee sells at $p\left(q^{*}\right)$.

Regardless of a buyer's willingness to pay, he would rather buy a cheaper unit than a more expensive one. Therefore the cheaper units will have to be rationed among buyers. We assume that all of the cheaper units are sold, but that some of the higher-priced supply might remain unsold. A customer might buy from the higherpriced firm if he cannot get a lower-priced unit, but only if his willingness to pay is above the higher price. But if most of the customers with relatively high willingness to pay manage to buy from the lower-priced firm, then the only remaining customers for the higher-priced firm are those with lower willingness to pay, who may choose instead to stay out of the market. Thus, the number of units that the higher-priced firm sells depends on the rationing rule.

It is clear that the licensor will not cut his supply below $q^{*} / 2$, because he would not do this even if he could sell all his units at the higher price required to clear the market, $p\left(q_{1}+q_{2}\right)=p\left(q_{1}+q^{*} / 2\right)$. Using (3.2), profit is increasing with $q_{1}$ at $q_{1}=q^{*} / 2$. Thus, for reducing the supply instead of increasing it $\left(d q_{1}<0\right.$ instead of $\left.d q_{1}>0\right)$, profit will decrease. The worry, as in the previous section, is not that the licensor will want to cut supply, but that he will want to increase it.

If the licensor increases supply, he will be the lower-priced firm selling all his 
units. However, the licensee may not sell all his units. We will describe the rationing rule by a decreasing (or nonincreasing) differentiable function $\hat{q}_{2}:\left[q^{*} / 2, \infty\right) \rightarrow\left[0, q^{*} / 2\right]$ where $\hat{q}_{2}\left(q_{1}\right)$ is the number of units that the licensee can sell if he produces $q^{*} / 2$ units and the licensor produces $q_{1}$ units, $q_{1}>q^{*} / 2$. We assume that $\hat{q}_{2}\left(q^{*} / 2\right)=q^{*} / 2$, which means that demand is exactly met if both firms produce $q^{*} / 2$, selling at the market-clearing price $p\left(q^{*}\right)$. Since the licensee cannot sell more than he produces, $\hat{q}_{2}\left(q_{1}\right) \leq q^{*} / 2$. In fact we shall assume that the licensees' sales, $\hat{q}_{2}$, decrease with $q_{1}$, to reflect rationing. If there are more lower-priced units, more consumers with high willingness to pay will be looking for them. By increasing supply and selling lower-priced units, the licensor crowds out sales by the licensee.

Two special cases are complete crowding out, so that $\frac{d \hat{q}_{2}\left(q_{1}\right)}{d q_{1}}=-1$, and no crowding out, so that $\frac{d \hat{q}_{2}\left(q_{1}\right)}{d q_{1}}=0$.

Then the licensor's profit function is the following.

$$
\begin{aligned}
\hat{\pi}^{1}\left(q_{1}, q_{2}\right) & =p\left(q_{1}+\hat{q}_{2}\left(q_{1}\right)\right) q_{1}+\rho \hat{q}_{2}\left(q_{1}\right)-\int_{0}^{q_{1}} \gamma(\hat{q}) d \hat{q} \\
& =\left(1-q_{1}-\hat{q}_{2}\left(q_{1}\right)\right) q_{1}+\rho \hat{q}_{2}\left(q_{1}\right)-\int_{0}^{q_{1}} \gamma(\hat{q}) d \hat{q} \\
& =\left(1-q_{1}\right) q_{1}-\left(q_{1}-\rho\right) \hat{q}_{2}\left(q_{1}\right)-\int_{0}^{q_{1}} \gamma(\hat{q}) d \hat{q}
\end{aligned}
$$

Taking the derivative with respect to $q_{1}$,

$$
\frac{\partial \hat{\pi}^{1}\left(q_{1}, q_{2}\right)}{\partial q_{1}}=\left(1-2 q_{1}\right)-\hat{q}_{2}\left(q_{1}\right)+\left(\rho-q_{1}\right) \frac{d \hat{q}_{2}\left(q_{1}\right)}{d q_{1}}-\gamma\left(q_{1}\right)
$$

Evaluating at $q_{1}=q_{2}=q^{*} / 2$, and using (3.12) and (3.2), the derivative is zero in the extreme case of complete crowding out, $\frac{d \hat{q}_{2}\left(q_{1}\right)}{d q_{1}}=-1$, but otherwise positive. Even with the fixed price, the licensor will behave opportunistically in increasing supply. The problem cannot be solved by making the royalty $\rho$ larger, since the licensee would not then be willing to produce $q^{*} / 2$ units.

In the special case of complete crowding out, the fixed-price license can support the profit maximum. With complete crowding out, the licensor is punished for his supply deviation by losing a lot of royalty revenue. However complete crowding is 
unlikely. It essentially means that all the customers with lower willingness to pay who could have been brought into the market by the licensor's increased supply have found themselves at the higher-priced firm, and therefore decide not to purchase. This would not happen with random assignment of customers to firms.

\subsection{Licensing a Patent Improvement to Oligopolists}

Suppose that a patented improvement is introduced to a market with two nonproprietary oligopolists instead of a competitive market. Suppose, in particular, that there are only two gasoline sellers, firms 1 and 2, and no further threat of entry. The amount of profit that the licensor can collect from the oligopolists depends on how he licenses, for example, by auctioning licenses or making take-it-or-leave it offers. For a discussion of how these differences matter for licensing a cost-reducing innovation, see Kamien (1992). We assume here that the licensor makes a take-it-or-leave-it offer which either licensee can refuse.

A license on the additive cannot have a royalty or wholesale price greater than $\Delta$, since a refiner can sell the same amount of unenhanced gasoline at price $p-\Delta$ as enhanced gasoline at price $p$. If the royalty is greater than $\Delta$, it is more profitable to sell unenhanced gasoline. This is true both for both perfect competitors and oligopolists.

If both oligopolists license at royalty $\rho \leq \Delta$ and sell the enhanced gasoline, firm 1 chooses the supply $q_{1}$ that maximizes profit, defined as follows, assuming that the supply $q_{2}$ of the other firm is fixed:

$$
\left(1+\Delta-q_{1}-q_{2}\right) q_{1}-(c+\rho) q_{1}
$$

The optimal $q_{1}$ solves

$$
q_{1}=\frac{1}{2}\left(1+\Delta-q_{2}-(c+\rho)\right)
$$


and at the symmetric solution where $q_{1}=q_{2}$, the firms supply

$$
q_{1}=q_{2}=\frac{1}{3}(1+\Delta-c-\rho)
$$

Thus, the licensor's royalty income is

$$
\rho\left(q_{1}+q_{2}\right)=\frac{2}{3} \rho(1+\Delta-c-\rho)
$$

Exactly as for the competitive case, the optimum is to set $\rho=\Delta$ provided $\Delta \leq 1-c$. (If $\Delta>1-c$, the licensor will give an exclusive license to a single gasoline supplier, who will charge the monopoly price (4.2). The other gasoline supplier will not find it profitable to compete.) The oligopoly price is then

$$
\begin{aligned}
p\left(q_{1}+q_{2}\right) & =1+\Delta-q_{1}-q_{2}= \\
& =(1+\Delta)\left(1-\frac{2}{3}\right)+\frac{2}{3}(\rho+c) \\
& =\frac{1}{3}(1+2 c)+\Delta
\end{aligned}
$$

which is $\Delta$ more than the oligopoly price in the absence of the improvement. Thus, with licensing, consumers are as well off as without licensing, and the licensor collects

profit in amount $\Delta$ per user, as justified by the derived-reward principle, just as when the gasoline market is competitive.

\subsection{Cross Licensing when firms have increasing marginal cost}

We augment section 4, showing why royalties must satisfy (4.21) in order for the cross license to support the monopoly price for the enhanced good, assuming that the inferior product is not supplied. Taking as given the royalties $\left(\rho_{1}, \rho_{2}\right)$ and firm 2's supply, $q_{2}$, firm 1's profit, as a function of its own supply $q_{1}$, is

$$
\left(p\left(q_{1}+q_{2}\right)-\rho_{1}-\int_{0}^{q_{1}} \gamma(z) d z\right) q_{1}
$$


and the profit-maximizing quantity satisfies

$$
q_{1}=\frac{1}{2}\left(1+\Delta-q_{2}-\rho_{1}-\gamma\left(q_{1}\right)\right)
$$

Similarly, firm 2's profit-maximizing quantity satisfies

$$
q_{2}=\frac{1}{2}\left(1+\Delta-q_{1}-\rho_{2}-\gamma\left(q_{2}\right)\right)
$$

By adding (4.17) and (4.18), setting $q_{1}=q_{2}=\frac{1}{2} q^{*}(\Delta)$, it follows that

$$
\begin{aligned}
& q_{1}+q_{2}=\frac{2}{3}(1+\Delta)-\frac{1}{3}\left(\rho_{1}+\rho_{2}\right)-\frac{1}{3}\left(\gamma\left(q_{1}\right)+\gamma\left(q_{2}\right)\right) \text { and } \\
& \left(\rho_{1}+\rho_{2}\right)=\frac{1}{2}(1+\Delta)-\frac{1}{2} \gamma\left(\frac{q^{*}(\Delta)}{2}\right)
\end{aligned}
$$

instead of (4.14). Since the royalty rates must be equal in order to sustain equal output, (4.21) follows. 


\section{References}

Adelman, M. J. 1977. "Use of Property as Clandestine Cartel." American Journal of Comparative Law 30:271-297.

Adelman, M. J., and F. K. Juenger. 1975. "Patent-Antitrust: Patent Dynamics and Field-of-Use Licensing." New York University Law Review. 50:273-308

Areeda, P. E., and H. Hovenkamp. 2003. Antitrust Law: An Analysis of Antitrust Principles and Their Application. New York: Aspen Publishers.

Arthur J. Schmitt Foundation v. Stockham Valves and Fittings, Inc., 292 F. Supp. 893 (N.D. Ala. 1966).

Baxter, W. 1966. Legal Restrictions on Exploitation of the Patent Monopoly: An Economic Analysis, Yale Law Journal 76:267-370

Bork, R. H. 1965. "The Rule of Reason and the Per Se Concept: Price Fixing and Market Division." Yale Law Journal 74:775-847.

Bork, R.H. 1978. The Antitrust Paradox: A Policy at War With Itself. New York: Basic Books.

Bowman, W. S. 1973. Patent and Antitrust Law: A Legal and Economic Appraisal. Chicago: University of Chicago Press.

Brulotte v. Thys Co., 379 U.S. 29, 85 S.Ct. 176, 13 L.Ed.2d 99 (1964).

California Dental Assn. v. FTC, 526 U.S. 756, 119 S.Ct. 1604, 143 L.Ed.2d 935 (1999).

Chisum, D. S. 2003. Chisum on Patents: A Treatise on the Law of Patentability, Validity and Infringement. Newark \& San Francisco: Matthew Bender \& Co.

Ethyl Gasoline Corp. v. U.S., 309 U.S. 436, 60 S.Ct. 618, 84 L.Ed. 852 (1940).

Gabscewicz, J., and J.-F. Thisse. 1980. "Entry (and Exit) in a Differentiated Industry." Journal of Economic Theory 22:327-338. 
General Talking Pictures Corp. v. Western Electric Co., 305 U.S. 124, 59 S.Ct. 116, 83 L.Ed 81 (1938).

Gifford, D. J. 2002. "The Antitrust/Intellectual Property Interface: An Emerging Solution to an Intractable Problem." Hofstra Law Review 31:398-418.

Hensley Equip. Co., Inc. v. Esco Corp., 383 F.2d 252 (5th Cir. 1967).

Hovenkamp, H., M. D. Janis, and M. A. Lemley 2004, IP and Antitrust: An Analysis of Antitrust Principles Applied to Intellectual Property Law. New York: Aspen Publishers.

Interstate Circuit v. U.S., 306 U.S. 208, 59 S.Ct. 467, 83 L.Ed. 610 (1939).

Kamien, M. I. 1992. "Patent Licensing." In R. Aumann, and S. Hart, eds., Handbook of Game Theory, 331-354. Amsterdam: North-Holland/Elsevier Science.

Kaplow, L. 1984. "The Patent-Antitrust Intersection: A Reappraisal." Harvard Law Review 97:1813-1912.

Landes, W. M. and R.A. Posner. 2003. The Economic Structure of Intellectual Property Law. Cambridge, MA: Belknap Press of Harvard University Press.

Neal Report (White House Task Force Report on Antitrust Policy), 1969. Antitrust EG Trade Regulation Reports 411 (Pt. 2).

American Bar Association Section of Antitrust Law 2002. The Federal Antitrust Guidelines for the Licensing of Intellectual Property: Origins and Applications (ABA Publishing $2 \mathrm{~d}$ ed.).

Morton Salt v. G.S. Suppiger Co., 314 U.S. 488, 62 S.Ct. 402, 86 L.Ed. 363 (1942).

Patterson, M. R. 2002. "When is Property Intellectual: The Leveraging Problem." Southern California Law Review 73:1133-1160

Royal Industries v. St. Regis Paper Co., 420 F.2d 449 (9th Cir. 1969).

Schlicher, J. W. 2002. Patent Law: Legal and Economic Principles. Eagan MN: Thomson/West. 
Scotchmer, S. 1991. "Standing on the Shoulders of Giants: Cumulative Research and the Patent Law." Journal of Economic Perspectives 5:29-41.

Scotchmer, S. 2005. Innovation and Incentives. Cambridge, MA: MIT Press.

Shapiro, C. 2003. "Antitrust Limits to Patent Settlements." RAND Journal of Economics 34:391-411.

Shapiro v. General Motors Corp., 472 F. Supp. 636 (D. Md. 1979).

U.S. v. Line Material Co. 333 US 287, 68 S.Ct. 550, 92 L.Ed. 701 (1948)

U.S. v. General Electric Co., 272 U.S. 476, 47 S.Ct. 192, 71 L.Ed. 362 (1926).

U.S. v. E.I. du Pont De Nemours 6 Co., 118 F. Supp. 41 (D. Del. 1953).

Weinschel, A.J. 2000. Antitrust-Intellectual Property Handbook (Glasser LegalWorks, Little Falls N.J.) 